\title{
Spectrophotometric Determination of Metoclopramide Hydrochloride in Pharmaceutical Preparations Using Diazotization Reaction
}

\author{
Lamya A. Sarsam \\ Salim A. Mohammed \\ Kasim M. Al-Abbasi \\ Department of Chemistry \\ College of Science \\ Mosul University
}

(Received 19/12/2010;Accepted 4/4/2011)

\begin{abstract}
A simple, rapid and sensitive spectrophotometric method has been developed for the quantitative determination of metoclopramide hydrochloride in both pure form and in its pharmaceutical formulations. The method is based on diazotization of primary amine group of metoclopramide hydrochloride with sodium nitrite and nitric acid followed by coupling with 8-hydroxyquinoline in alkaline medium to form a pinkish - red coloured species, which showed a maximum absorption at $528 \mathrm{~nm}$ against reagent blank. Beer's law was obeyed over the concentration range of $5-300 \mu \mathrm{g} / 25 \mathrm{ml}$. with a molar absorptivity $3.1 \times 10^{4}$ 1. $\mathrm{mol}^{-1} \cdot \mathrm{cm}^{-1}$. The method is suitable for the determination of metoclopramide hydrochloride in the presence of other ingredients that are usually present in dosage forms and the recoveries were obtained in the range of $98.9-100.0 \%$. The method does not resort to temperature control or to solvent extraction. The effect of organic solvent on the spectrophotometric properties of the azo dye, the composition and stability constant have been worked out. The method has been successfully applied to the determination of metoclopramide in its pharmaceutical preparations ( tablet, syrup and drop ) .
\end{abstract}

Keywords: metoclopramide- $\mathrm{HCl}$, determination , 8-hydroxyquinoline, spectrophotometry

\section{القدير الاليف لإيدوكلوربدميتوكلوسرلميدفي بهض المستحضرات الصيدلانية بلستخدل

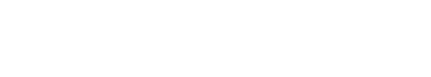

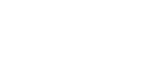

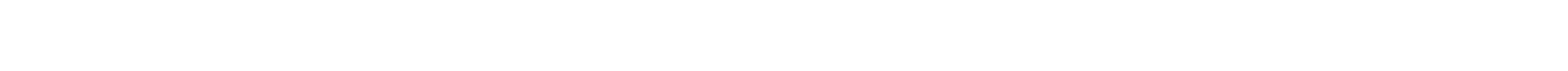

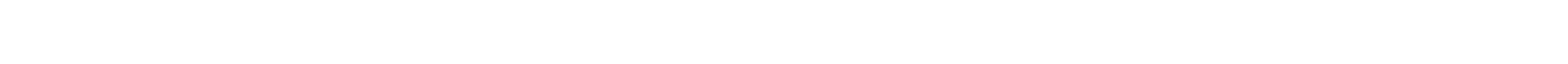

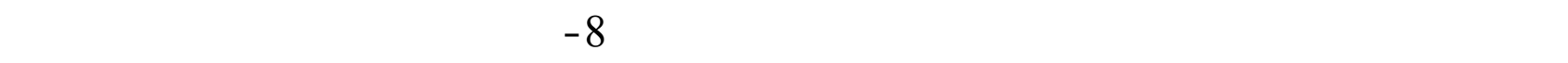

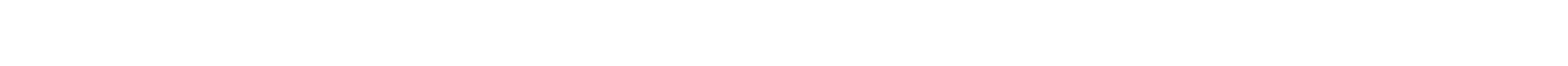

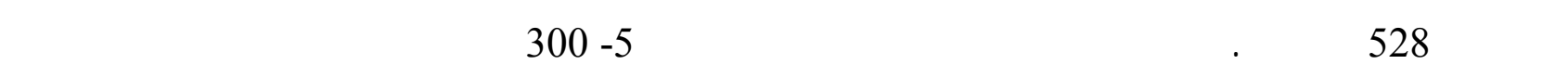




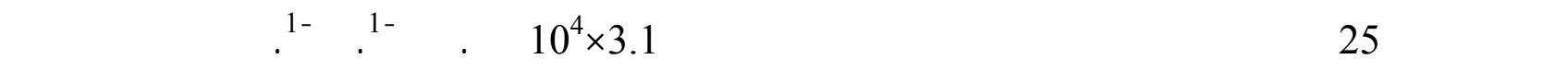
لا تحتاج إلى اللسطرة على درجلت الحرارة أو الاستخلاص بالمنيب. لقد تمت درلسة تأثيدير عدد من المذيبات

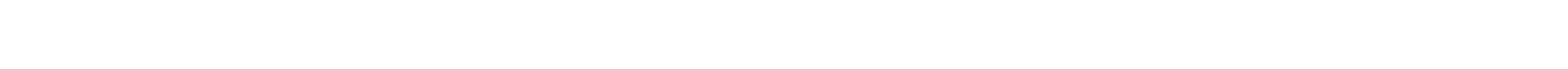

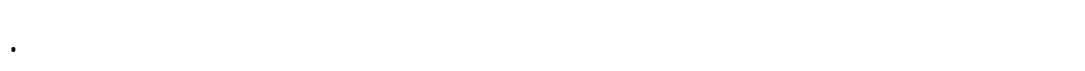

\section{INTRODUCTION}

Metoclopramide hydrochloride (MCP), 4-amino-5-chloro-2-methoxy-N-(2diethylamino-ethyl) benzamide, is used as an anti-emetic in the treatment of some forms of nausea and vomiting and also to increase gastrointestinal motility. It is of little benefit in the prevention for treatment of motion sickness or in the treatment of nausea and vertigo due to Meniere disease or other labyrinth disturbance (Tas et al., 2006). Many analytical methods have been developed for the determination of MCP, the most of them are spectrophotometric methods based on diazotization and coupling with dibenzoylmethane (Revanasiddappa and Manju, 2001), benzoylacetone (Omran, 2005), aniline (Shah et al., 2005), $\beta$-naphthol (Patel et al., 2006), impramine hydrochloride (Revanasiddappa and Veena, 2006) and 2,4-dihydroxyacetophenone (Khalil, 2010). other spectrophotometric methods involve iona ssociation complex formation (Abdel-Gawad and El-Guindi, 1995), an oxidative coupling reaction (Al-Talib and Mohammed, 1996; Ahmed and Ali, 2006), charge-transfer complex formation (Al-Gabsha et al., 2004), Redox reaction (Amin and Ragab, 2003), or through formation of the Schiff's base with p(dimethylamino) cinamaldehyde (Moussa, 2000). Other methods based on fluorimetric (Attia and Aboaly, 2010), Flow injection (Al-Arfaj, 2004), chromatographic techniques (Radwan, 1998, Cossa et al., 2008; Shaabani and Adergani, 2009), voltammetry (Farghaly et al., 2005) and $\mathrm{H}^{1}$ NMR spectroscopy (Hanna and Lau-Cam, 1991). Some of these methods suffer from several disadvantage, such as, use of heating step, low range of determination and critical working conditions and poor selectivity. Other methods are typically less sensitive, relatively complicated, or require expensive instrumentation. The British pharmacopoeia reported a potentiometric method using perchloric acid solution for the determination of MCP powder and a UV method for tablets and ampoules (British Pharmacopoeia, 1998). The potentiometric method requires about $250 \mathrm{mg}$ of drug, whereas the UV method is liable to interferences from tablets excipients, and requires pre-extraction with chloroform. These deficiencies have encouraged the authors to develop a simple, selective, sensitive and inexpensive method for the analysis of the studied drug. The present work describes the application of 8-hydroxyquinoline as a coupling agent for the determination of MCP in both pure form and pharmaceutical preparations.

\section{EXPERAMENTAL}

\section{Apparatus}

The absorption spectra were recorded on a double-beam Shimadzu UV-Visible recording spectrophotometer UV-160 with $1.0 \mathrm{~cm}$ matched silica cells. The absorbance measurements were obtained using single-beam Unico 1100 spectrophotometer with $1-\mathrm{cm}$ plastic cells. pH measurements were preformed using Philips PW 9420 pH meter. 


\section{Reagents}

All chemical used were of analytical grade reagent.

- MCP (100 $\mathrm{\mu g} / \mathrm{ml})$ solution. It was prepared by dissolving $0.01 \mathrm{~g}$ of MCP in distilled water and the volume was completed to $100 \mathrm{ml}$ with distilled water in a volumetric flask. The solution was then transferred to a dark bottle and is stable for at least one month. Working solution of MCP was prepared by appropriate dilution of the stock solution with distilled water.

- 8-Hydroxyquinoline (0.2 \%) solution. It was prepared by dissolving $0.20 \mathrm{~g}$ of 8 hydroxyquinoline reagent (Hopkin and Williams) in $2 \mathrm{ml}$ acetic acid and the volume was completed to $100 \mathrm{ml}$ with distilled water in a volumetric flask.

- Sodium nitrite (1\%) solution. This solution has been prepared by dissolving $1.0 \mathrm{~g}$ of sodium nitrite $(\mathrm{BDH})$ in $100 \mathrm{ml}$ distilled water.

- Sulphamic acid solution, 3\% (w/v). This solution was prepared by dissolving $3.0 \mathrm{~g}$ of sulphamic acid (Fluka) in $100 \mathrm{ml}$ distilled water.

- Solutions of $\mathbf{1 M ~ K O H}$ and $1 \mathrm{M} \mathrm{HNO}$ were also prepared.

\section{Recommended Procedure and calibration curve}

An aliquot of standard solution (5-500) $\mu \mathrm{g}$ of MCP was transferred into a series of 25$\mathrm{ml}$ volumetric flask. To each flask, $1 \mathrm{ml}$ of nitric acid solution and $0.5 \mathrm{ml} \mathrm{1 \%}$ sodium nitrite solution were added. The reaction mixture was allowed to stand for $5 \mathrm{~min}$ after mixing thoroughly. A $0.3 \mathrm{ml}$ of $3 \%$ sulphamic acid solution was added with occasional shaking for $4 \mathrm{~min}$ followed by addition of $2.5 \mathrm{ml}$ of $0.2 \% 8$-hydroxyquinoline, the solutions were left for $3 \mathrm{~min}$ at room temperature and $3 \mathrm{ml}$ of $1 \mathrm{M}$ potassium hydroxide was added and the contents were diluted to the mark with distilled water and mixed well. The absorbance of the formed coloured azo dye was measured at $528 \mathrm{~nm}$ against the corresponding reagent blank. A linear calibration graph was obtained over the concentration range of (5-300) $\mu \mathrm{g}$ of $\mathrm{MCP} / 25 \mathrm{ml}$. Higher concentrations show a negative deviation from Beer's law (Fig.1). The apparent molar absorptivity has been found to be $3.1 \times 10^{4} 1 . \mathrm{mol}^{-1} . \mathrm{cm}^{-1}$.

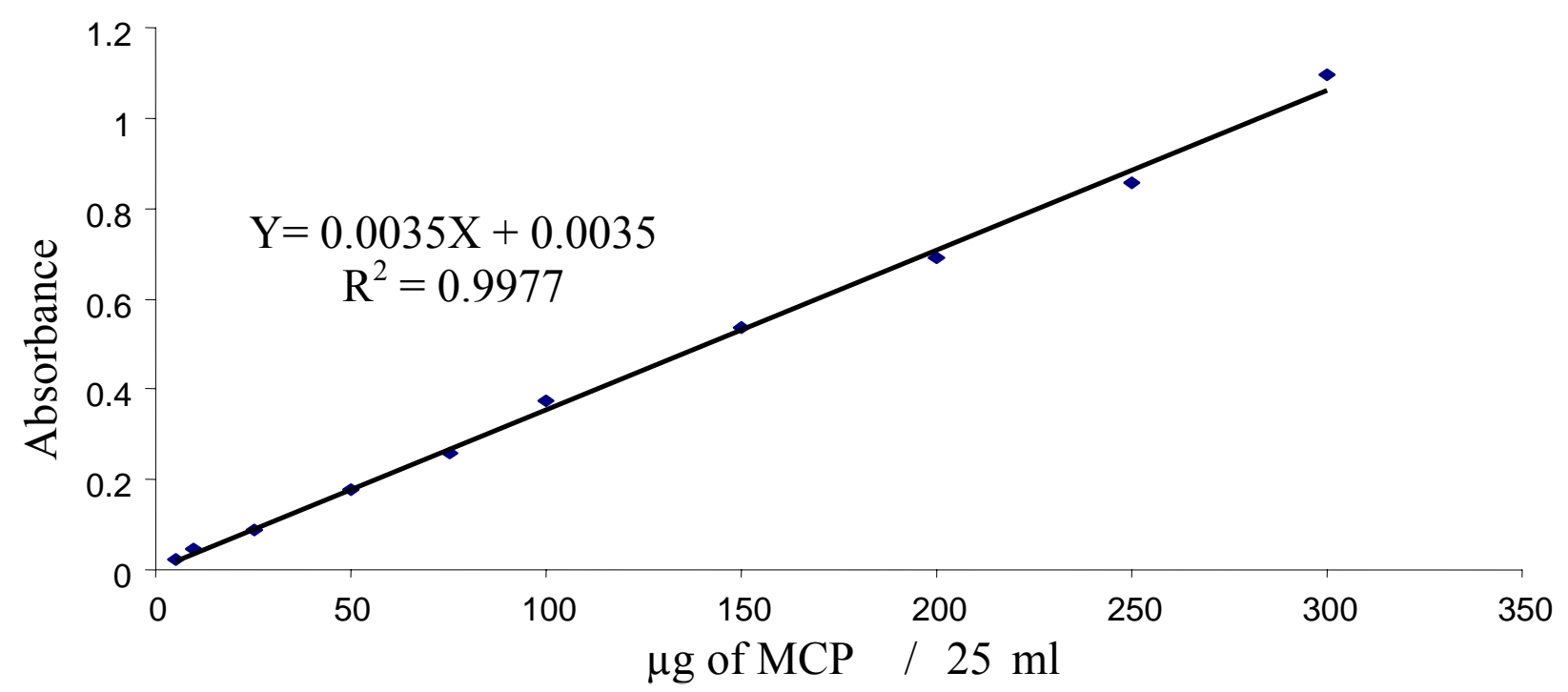

Fig. 1. Calibration graph for MCP determination 


\section{Procedure for dosage forms}

For tablets: A ten tablets ( $5 \mathrm{mg} \mathrm{MCP}-\mathrm{HCl} /$ tablet $)$ of the drug were weighed, powdered and mixed well. A portion equivalent to $0.01 \mathrm{~g}$ was weighed and dissolved in 50 $\mathrm{ml}$ of distilled water, shaken well, filtered and diluted with water to $100 \mathrm{ml}$ in a volumetric flask. An aliquot of the diluted drug solution was then treated as done in a recommended procedure.

For syrups: The content of the container of MCP syrup ( $5 \mathrm{mg} \mathrm{MCP}-\mathrm{HCl} / 5 \mathrm{ml}$ ) was mixed well and $2 \mathrm{ml}$ of the syrup was quantitatively transferred into $100 \mathrm{ml}$ volumetric flask and completed to the work with distilled water. An aliquot of the diluted drug solution was then treated as done in recommended procedure.

For drops: An accurate volume $2.5 \mathrm{ml}$ of $\mathrm{MCP}$ drops $(4 \mathrm{mg} \mathrm{MCP}-\mathrm{HCl} / \mathrm{ml})$ was transferred into a $100 \mathrm{ml}$ volumetric flask and completed to the mark with distilled water, then it was proceeded as described under recommended procedure.

\section{RESULTS AND DISCUSSION}

\section{Principle of the colour reaction}

Under the reaction conditions, metoclopramide was treated with nitrite solution in acidic medium, which undergoes diazotization reaction to give the diazonium salt. The diazonium salt was coupled with 8-hydroxyquinoline as a coupling agent in a basic medium to form an intensely-coloured azo dye :<smiles>[R]C(=O)c1cc(Cl)c(N)cc1OC</smiles><smiles>[R]C(=O)c1cc(Cl)c(N=N)cc1OC</smiles>

Diazonium ion

$$
\mathrm{R}=-\mathrm{NH}\left(\mathrm{CH}_{2}\right)_{2} \mathrm{~N}\left(\mathrm{C}_{2} \mathrm{H}_{5}\right)_{2}
$$

The formed coloured dye exhibited absorption maxima at $528 \mathrm{~nm}$ against reagent blank solution. The intensity of the formed dye has been found to be proportional to the amount of metoclopramide originally present in solution. 


\section{Effect of diazotization acid}

Different amount of various acids such as $\mathrm{HCl}, \mathrm{CH}_{3} \mathrm{COOH}, \mathrm{HNO}_{3}$ and $\mathrm{H}_{2} \mathrm{SO}_{4}$ have been studied in diazotization of MCP for the purpose of producing intense coloured dye, strong colour contrast and lower blank value. The experimental results showed that $1 \mathrm{ml}$ of $1 \mathrm{M} \mathrm{HNO}_{3}$ solution was selected for the reaction because it gave high intensity for the dye with a corresponding low reagent blank absorbance.

\section{Effect of sodium nitrite amount and time}

The effect of different amount (0.1-2.0) $\mathrm{ml}$ of $1 \%$ sodium nitrite with time on the absorbance of the resulting azo dye has been investigated. The results in Table 1 show that $0.5 \mathrm{ml}$ of $1 \%$ sodium nitrite solution with 5 min reaction time was optimum and it was recommended for the subsequent experiment .

Table 1: Effect of sodium nitrite amount and time on absorbance.

\begin{tabular}{|c|c|c|c|c|c|c|c|}
\hline \multirow{2}{*}{$\begin{array}{c}\text { ml of NaNO } \\
\text { solution (1\%) }\end{array}$} & \multicolumn{7}{|c|}{ Absorbance / min standing time } \\
\cline { 2 - 8 } & $\mathbf{0}$ & $\mathbf{1}$ & $\mathbf{2}$ & $\mathbf{3}$ & $\mathbf{4}$ & $\mathbf{5}$ & $\mathbf{7}$ \\
\hline 0.1 & 0.210 & 0.215 & 0.215 & 0.200 & 0.232 & 0.256 & 0.251 \\
\hline 0.3 & 0.222 & 0.242 & 0.239 & 0.239 & 0.239 & 0.254 & 0.243 \\
\hline 0.5 & 0.249 & 0.249 & 0.247 & 0.256 & 0.225 & 0.305 & 0.300 \\
\hline 0.7 & 0.264 & 0.242 & 0.255 & 0.250 & 0.243 & 0.258 & 0.257 \\
\hline 1.0 & 0.285 & 0.271 & 0.256 & 0.279 & 0.266 & 0.261 & 0.234 \\
\hline 2.0 & 0.237 & 0.254 & 0.258 & 0.249 & 0.265 & 0.268 & 0.221 \\
\hline
\end{tabular}

\section{Effect of sulphamic acid amount and time}

It was found from the experimental results that $0.3 \mathrm{ml}$ of $3 \%$ sulphamic acid with 4 min standing time have been incorporated for the development of the formed coloured azo dye (Table 2).

Table 2: Effect of sulphamic acid amount and time on absorbance.

\begin{tabular}{|c|c|c|c|c|c|c|c|}
\hline \multirow{2}{*}{$\begin{array}{c}\text { ml of } 3 \% \text { sulphamic } \\
\text { acid }\end{array}$} & \multicolumn{7}{|c|}{ Absorbance / min standing time } \\
\hline & & 0 & 1 & 2 & 3 & 4 & 5 \\
\hline \multirow{2}{*}{0.1} & $\mathrm{~S}$ & 0.214 & 0.295 & 0.239 & 0.202 & 0.298 & 0.274 \\
\hline & B & 0.008 & 0.004 & 0.010 & 0.008 & 0.000 & 0.003 \\
\hline \multirow{2}{*}{0.3} & $S$ & 0.219 & 0.248 & 0.258 & 0.369 & 0.378 & 0.273 \\
\hline & B & 0.003 & 0.006 & 0.000 & 0.004 & 0.000 & 0.004 \\
\hline \multirow{2}{*}{0.5} & S & 0.222 & 0.274 & 0.271 & 0.279 & 0.278 & 0.278 \\
\hline & B & 0.008 & 0.007 & 0.000 & 0.004 & 0.000 & 0.004 \\
\hline \multirow{2}{*}{0.7} & $\mathrm{~S}$ & 0.192 & 0.298 & 0.254 & 0.279 & 0.282 & 0.247 \\
\hline & B & 0.008 & 0.010 & 0.000 & 0.003 & 0.000 & 0.003 \\
\hline
\end{tabular}




\section{Effect of 8-hydroxyquinoline amount}

The effect of 8-hydroxyquinoline amount on the absorbance of the azo dye has been studied (Table 3). It was observed from the results that $2.5 \mathrm{ml}$ of $0.2 \% 8$-hydroxyquinoline solution and $3 \mathrm{~min}$ of reaction time was the more suitable to give the highest intensity value for the azo dye.

Table 3: Effect of 8-hydroxyquinoline amount.

\begin{tabular}{|c|c|c|c|}
\hline \multirow{2}{*}{$\begin{array}{c}\text { ml of 8-hydroxyquinoline (0.2\%) } \\
\text { solution }\end{array}$} & \multicolumn{3}{|c|}{ Absorbance / min standing } \\
\cline { 2 - 4 } & $\mathbf{0}$ & $\mathbf{1}$ & $\mathbf{3}$ \\
\hline 0.25 & 0.199 & 0.234 & 0.264 \\
\hline 0.5 & 0.195 & 0.204 & 0.229 \\
\hline 1.5 & 0.242 & 0.246 & 0.264 \\
\hline 2.0 & 0.227 & 0.239 & 0.298 \\
\hline 2.5 & 0.307 & 0.318 & 0.321 \\
\hline 3.0 & 0.087 & 0.063 & 0.046 \\
\hline 4.0 & 0.067 & 0.043 & 0.034 \\
\hline
\end{tabular}

\section{Effect of base}

The preliminary investigations showed that the coupling of 8-hydroxyquinoline with diazotized metoclopramide to produce the coloured azo dye was developed only in a basic medium. Therefore, different amounts (1-3 $\mathrm{ml}$ of $1 \mathrm{M}$ solutions) of various bases have been examined for the purpose of producing intense coloured dye with a strong colour contrast and lower blank value. The results indicate that the formation of the coloured azo dye needs a strong basic medium (Table 4). Sodium carbonate and ammonium hydroxide exhibited weak colour contrast which is apparently due to $\mathrm{pH}$ variation. Therefore, $3 \mathrm{ml}$ of $1 \mathrm{M} \mathrm{KOH}$ has been recommended for the subsequent experiments.

Table 4: Effect of base on absorbance.

\begin{tabular}{|c|c|c|c|}
\hline Base used & \multicolumn{3}{|c|}{ Absorbance / ml of base added } \\
\cline { 2 - 4 }$(\mathbf{1 M})$ & $\mathbf{1}$ & $\mathbf{2}$ & $\mathbf{3}$ \\
\hline $\mathrm{NaOH}$ & 0.015 & 0.293 & 0.216 \\
\hline $\mathrm{Na}_{2} \mathrm{CO}_{3}$ & 0.039 & 0.033 & 0.036 \\
\hline $\mathrm{NH}_{4} \mathrm{OH}$ & 0.018 & 0.011 & 0.012 \\
\hline $\mathrm{KOH}$ & 0.022 & 0.356 & $0.360^{*}$ \\
\hline \multicolumn{2}{|c}{$* \mathrm{pH}$ of the final solution $=12.6$} \\
\hline
\end{tabular}

\section{Effect of surfactants}

The presence of surfactants in a coloured reaction mixture solution may frequently lead to an increase in the absorbance and a shift in the wavelength to higher values. In this respect, sodium dodecyl sulphate (SDS) (anionic surfactant), cetyltrimethylammonium bromide (CTAB) (cationic surfactant) and Triton X-100 (non-ionic surfactant) have been 
introduced. The results indicated that addition of surfactants gave no useful effect. Therefore, they were omitted in this study.

\section{Development time and stability period}

To test the effect of time on the absorbance of the coloured dye at $528 \mathrm{~nm}$, the coloured dye has been prepared from different amounts of metoclopramide under the optimal experimental conditions, and the absorbance were measured at different intervals of time up to $60 \mathrm{~min}$. The experimental results shown in Table 5 indicate that the coloured dye develops immediately and the absorbance remains maximum and constant for at least 30 minutes.

Table 5: Effect of time and concentration on absorbance.

\begin{tabular}{|c|c|c|c|c|c|c|c|c|c|c|}
\hline \multirow{2}{*}{$\begin{array}{c}\text { 4g of } \\
\text { MCP }\end{array}$} & \multicolumn{10}{|c|}{ Absorbance / min } \\
\cline { 2 - 13 } & $\mathbf{0}$ & $\mathbf{5}$ & $\mathbf{1 0}$ & $\mathbf{1 5}$ & $\mathbf{2 0}$ & $\mathbf{2 5}$ & $\mathbf{3 0}$ & $\mathbf{4 0}$ & $\mathbf{5 0}$ & $\mathbf{6 0}$ \\
\hline 5 & 0.020 & 0.023 & 0.023 & 0.024 & 0.023 & 0.024 & 0.023 & 0.042 & 0.037 & 0.032 \\
\hline 25 & 0.092 & 0.093 & 0.092 & 0.091 & 0.092 & 0.090 & 0.090 & 0.088 & 0.118 & 0.099 \\
\hline 50 & 0.180 & 0.181 & 0.183 & 0.182 & 0.184 & 0.183 & 0.181 & 0.172 & 0.164 & 0.165 \\
\hline 100 & 0.373 & 0.377 & 0.374 & 0.371 & 0.368 & 0.362 & 0.357 & 0.340 & 0.325 & 0.309 \\
\hline
\end{tabular}

\section{Absorption spectra}

Under the above optimized conditions, a pinkish-red coloured chromophore was formed by coupling of diazotized metoclopramide with 8-hydroxyquinoline in alkaline medium. This coloured dye exhibited an absorption maxima at $528 \mathrm{~nm}$ against reagent blank as shown in Fig.2. The corresponding reagent blank shows a negligible absorbance at this wavelength .

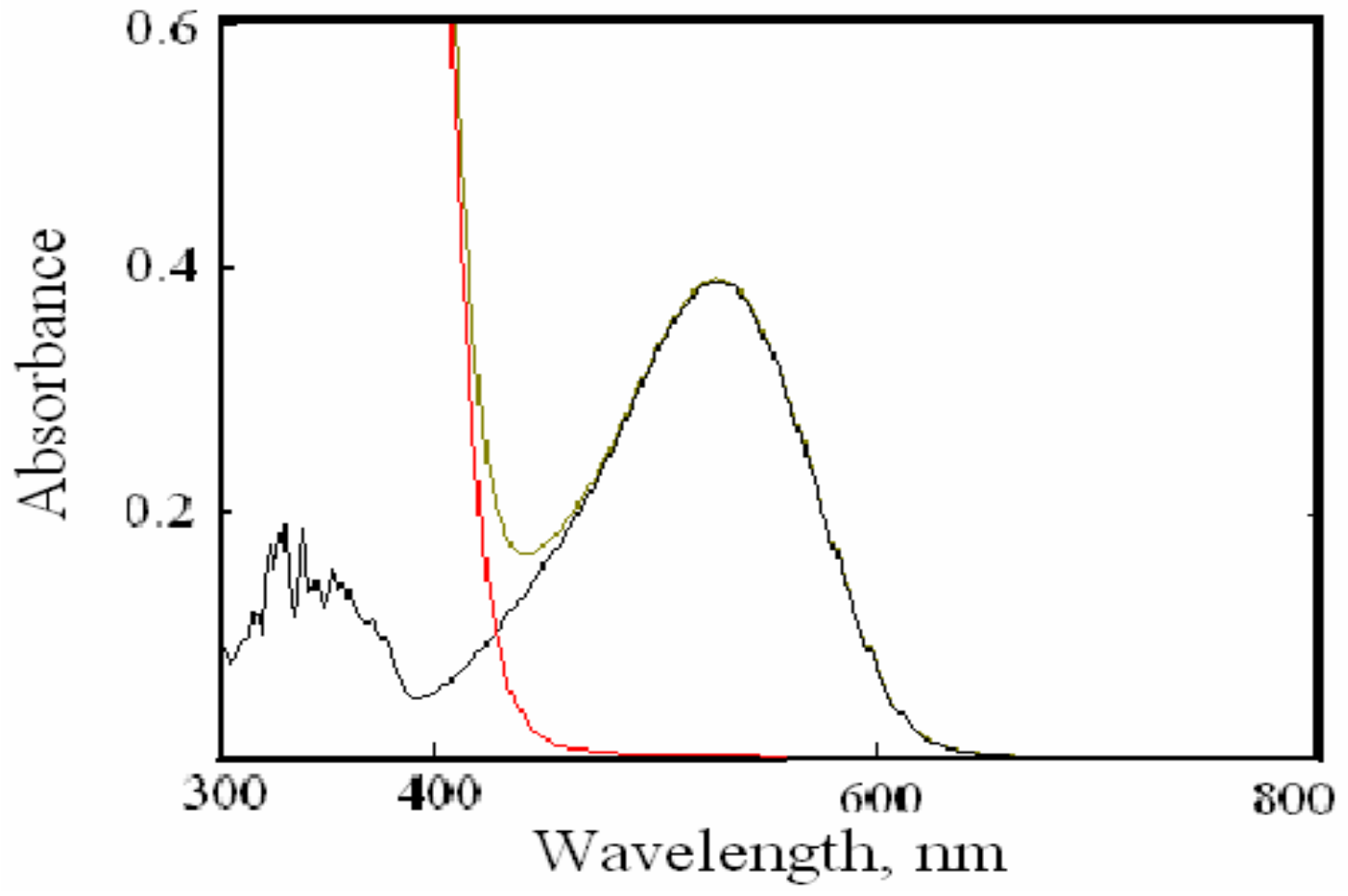


Fig. 2: Absorption spectra of $100 \mu \mathrm{g}$ of $\mathrm{MCP} / 25 \mathrm{ml}$ measured against (A) blank, (B) distilled water, and (C) blank measured against distilled water.

\section{Nature of the azo dye}

The stoichiometry of the product formed from the reaction of diazotized metoclopramide with 8-hydroxyquinoline was investigated by applying the continuous variations method (Job's method) Fig.3.

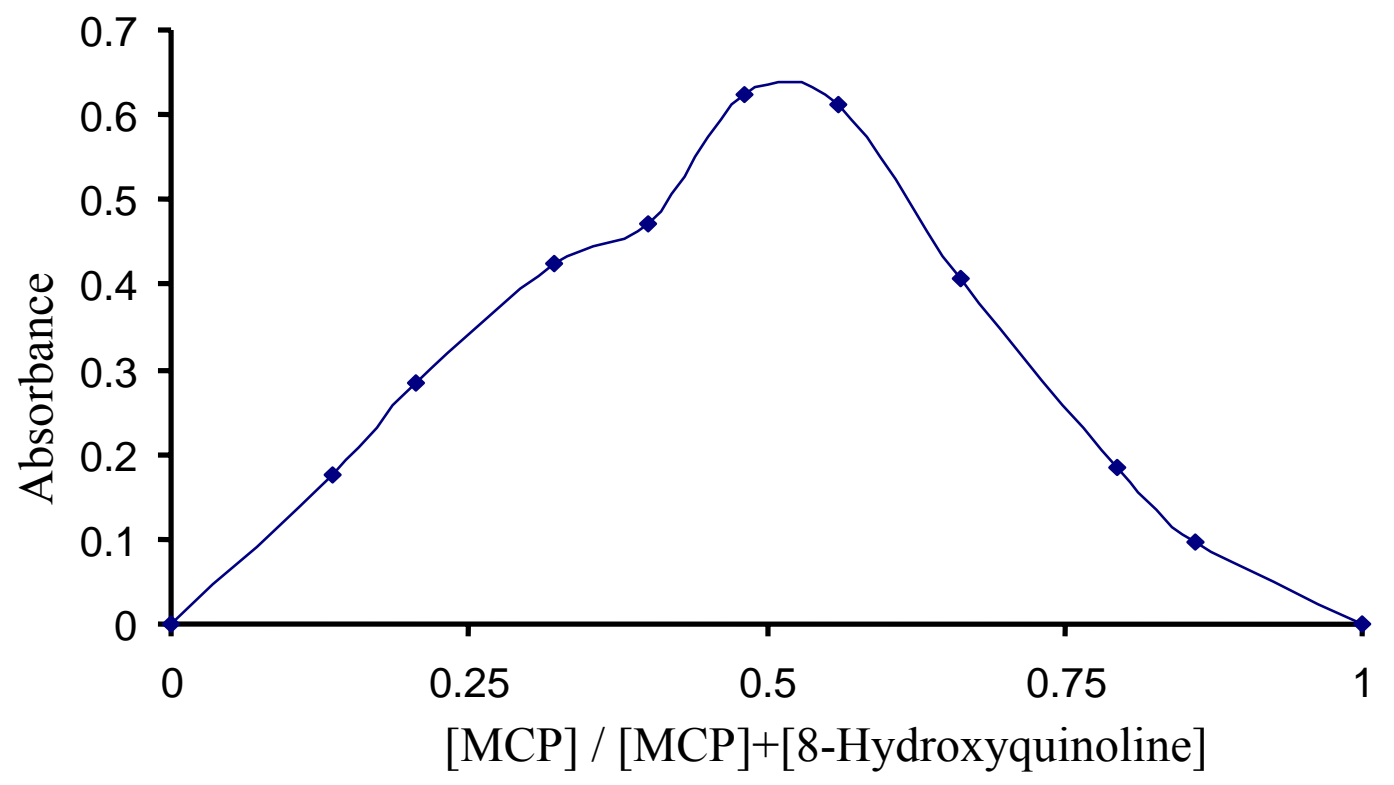

Fig. 3: Job's plot for diazotized MCP - 8-hydroxyquinoline azo dye.

The results indicate that the azo-dye was formed in a ratio of 1:1 indicating a mono azo dye with probably of the following structure.

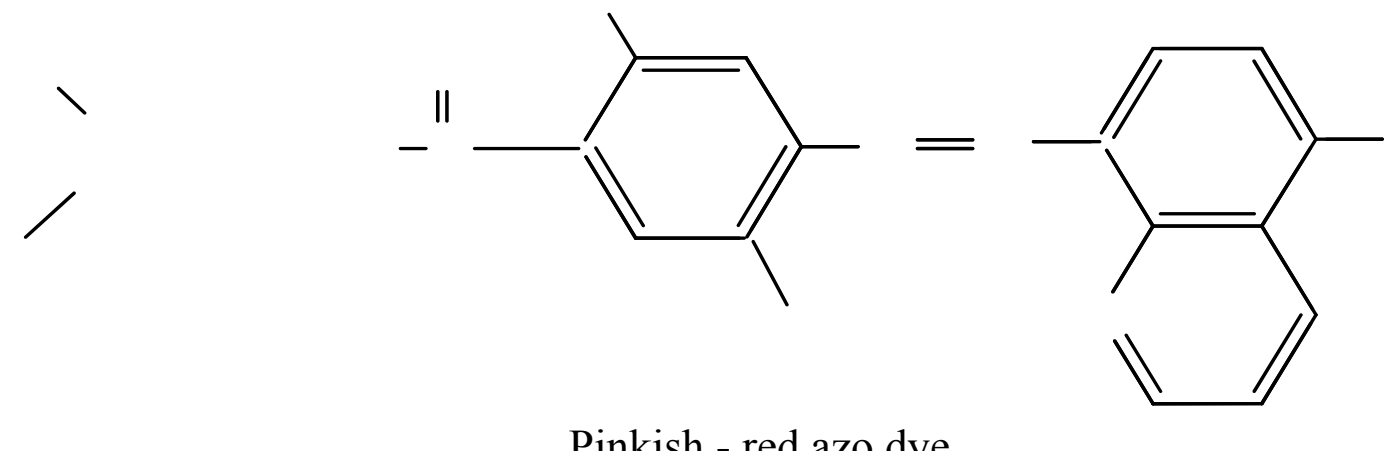

\section{Accuracy and precision}

To check the accuracy and precision of the proposed method, metoclopramide was determined at three different concentrations. The results shown in Table 6 indicate, that the method is satisfactory. 
Table 6: Accuracy and precision of the proposed method.

\begin{tabular}{|c|c|c|}
\hline $\begin{array}{c}\text { Amount of } \\
\text { metoclopramide taken, } \boldsymbol{\mu g}\end{array}$ & Recovery, \% * & Relative standard deviation, \% * \\
\hline 50 & 100.0 & \pm 0.64 \\
\hline 100 & 98.9 & \pm 0.38 \\
\hline 200 & 100.0 & \pm 0.50 \\
\hline
\end{tabular}

*Average of five determinations.

\section{Effect of organic solvents}

Different organic solvents are examined to evaluate their effects on the intensity of the resulting azo dye and the data are shown in Table 7 .

Table 7: Effect of water and organic solvents on the optical properties of the azo dye.

\begin{tabular}{|c|c|c|c|c|}
\hline \multirow{2}{*}{ Solvent } & \multicolumn{2}{|c|}{ Colour } & \multirow{2}{*}{$\lambda \max ,(\mathrm{nm})$} & \multirow{2}{*}{$\varepsilon, 1 . \mathrm{mol}^{-1} . \mathrm{cm}^{-1}$} \\
\cline { 2 - 3 } & Sample & Blank & & $0.8 \times 10^{3}$ \\
\hline Acetic acid & Yellow & Colourless & 400 & $0.68 \times 10^{3}$ \\
\hline Acetone & Pink & Yellow & 560 & $1.5 \times 10^{3}$ \\
\hline 1,4-Dioxane & Pink & Colourless & 536 & $1.4 \times 10^{3}$ \\
\hline Ethanol & Pink & Pale Yellow & 534 & $0.5 \times 10^{3}$ \\
\hline Formic acid & Yellow & Colourless & 400 & $0.6 \times 10^{3}$ \\
\hline Methanol & Yellow & Colourless & 442 & $1.6 \times 10^{3}$ \\
\hline n-Butanol & Orange & Pale Yellow & 478 & $3.1 \times 10^{4}$ \\
\hline Water & Pinkish-red & Colourless & 528 & \\
\hline
\end{tabular}

Water is still being the choice in the subsequent experiments due to its availability, nontoxicity as

well as from the sensitivity point of view.

\section{Effect of interferences}

In order to test the efficiency and selectivity of the proposed method, the effect of some foreign substances (e.g., acacia, glucose, lactose, lindocaine, menthol and starch), that usually present in dosage forms were studied by adding different amounts of foreign substances to $100 \mu \mathrm{g}$ metoclopramide $/ 25 \mathrm{ml}$. It was observed that the studied foreign species did not interfere in the present method (Table 8). 
Table 8: Effect of additives and excipients on the determination of $100 \mu \mathrm{g}$ of MCP.

\begin{tabular}{|c|c|c|c|}
\hline \multirow{2}{*}{ Interferences } & \multicolumn{3}{|c|}{$\begin{array}{l}\text { Recovery(\%) of } 100 \mu g \text { metoclopramide / } \mu \text { g of } \\
\text { interfere added }\end{array}$} \\
\hline & 100 & 500 & 1000 \\
\hline Acacia & 98.6 & 97.1 & 95.6 \\
\hline Glucose & 96.8 & 94.2 & 95.6 \\
\hline Lactose & 96.3 & 96.3 & 94.8 \\
\hline lindocaine & 95.6 & 96.8 & 101.4 \\
\hline Menthol & 98.6 & 99.1 & 100.8 \\
\hline Starch & 99.3 & 96.2 & 97.5 \\
\hline
\end{tabular}

\section{Application of the method}

The proposed method was successfully applied to the determination of Metoclopramide $-\mathrm{HCl}$ in its pharmaceutical preparations (tablet, syrup and drop). The results which are shown in Table 9 indicate that a good recovery was obtained.

Table 9: Analytical applications.

\begin{tabular}{|c|c|c|c|}
\hline \multirow{2}{*}{$\begin{array}{c}\text { Metoclopramide } \\
\text { amount, } \boldsymbol{\mu g}\end{array}$} & \multicolumn{3}{|c|}{ Recovery(\%) of metoclopramide* } \\
\cline { 2 - 4 } & $\begin{array}{c}\text { Meclodin } \\
\text { (5mg/ tablet) } \\
\text { NDI-Iraq }\end{array}$ & $\begin{array}{c}\text { Meclodin } \\
\text { syrup (5mg/5ml) } \\
\text { NDI-Iraq }\end{array}$ & $\begin{array}{c}\text { Meclodin } \\
\text { drops (4mg/ml) } \\
\text { NDI-Iraq }\end{array}$ \\
\hline 5 & 95.8 & 100.0 & 95.8 \\
\hline 50 & 95.0 & 95.0 & 100.0 \\
\hline 100 & 101.6 & 98.9 & 103.7 \\
\hline
\end{tabular}

* Average of five determinations.

The performance of the proposed method was assessed by calculating the student's ttest and F-test compared with the literature method (Khalil, 2010). The results in Table 10 show that the calculated values of $\mathrm{t}$ and $\mathrm{F}$ did not exceed the theoretical values at the $95 \%$ confidence level for eight degrees of freedom indicating that there is no significant difference between the proposed method and the literature method. 
Table 10: Determination of metoclopramide in pharmaceutical preparations.

\begin{tabular}{|c|c|c|c|c|c|c|}
\hline \multirow{2}{*}{ Drug } & \multirow{2}{*}{$\begin{array}{c}\text { MCP } \\
\text { amount, } \\
(\mu g)\end{array}$} & \multirow{2}{*}{$\begin{array}{c}\text { Pharmaceutical } \\
\text { preparation }\end{array}$} & \multicolumn{4}{|c|}{ Recovery, * \% } \\
\hline & & & $\begin{array}{l}\text { Present } \\
\text { method }\end{array}$ & $\begin{array}{l}\text { Literature method } \\
\text { (Khalil , 2010) }\end{array}$ & t-exp & F-exp \\
\hline $\begin{array}{c}\text { Meclodin } \\
\text { (5mg/ } \\
\text { tablet) } \\
\text { SDI-Iraq }\end{array}$ & 100 & Tablet & $\begin{array}{r}101.36 \pm \\
0.56\end{array}$ & $101.24 \pm 0.4$ & 0.4 & 3.9944 \\
\hline $\begin{array}{l}\text { Meclodin } \\
\text { (5mg/5ml) } \\
\text { SDI-Iraq }\end{array}$ & 100 & Syrup & $\begin{array}{c}99.24 \pm \\
0.5\end{array}$ & $98.62 \pm 0.37$ & 2.3 & 4.0062 \\
\hline $\begin{array}{l}\text { Meclodin } \\
\text { (4mg/ml) } \\
\text { NDI-Iraq }\end{array}$ & 100 & Drops & $\begin{array}{l}103.7 \pm \\
0.5\end{array}$ & $103.48 \pm 0.39$ & 1.6 & 1.8548 \\
\hline
\end{tabular}

* Average of five determinations.

\section{Comparison of the methods}

Table 11, shows the comparison between some of analytical variables for the present method with that of another literature spectrophotometric methods.

Table 11: Comparison of the methods.

\begin{tabular}{|c|c|c|c|}
\hline $\begin{array}{c}\text { Analytical } \\
\text { parameters }\end{array}$ & Present method & $\begin{array}{c}\text { Literature method } \\
\text { (Khalil, 2010) }\end{array}$ & $\begin{array}{c}\text { Literature method } \\
\text { (Al-Talib and } \\
\text { Mohammed, 1996) }\end{array}$ \\
\hline Coupling condition & Alkaline medium & Alkaline medium & Acidic medium \\
\hline$\lambda \max (\mathrm{nm})$ & 528 & 450 & 612 \\
\hline Reagent & 8 -Hydroxyquinoline & $\begin{array}{c}2,4- \\
\text { Hydroxyacetophenone }\end{array}$ & Phenothiazine \\
\hline Type of method & Azo coupling & Azo coupling & Oxidative coupling \\
\hline $\begin{array}{c}\text { Beer's law range, } \\
\text { ppm }\end{array}$ & $0.2-12$ & $0.4-12$ & $0.1-16$ \\
\hline $\begin{array}{c}\text { Molar absorptivity } \\
\text { 1.mol } \text {.cm }^{-1}\end{array}$ & $3.1 \times 10^{4}$ & $2.48 \times 10^{4}$ & $1.65 \times 10^{4}$ \\
\hline $\begin{array}{c}\text { Application of the } \\
\text { method }\end{array}$ & $\begin{array}{c}\text { Tablets , syrup and } \\
\text { drops }\end{array}$ & $\begin{array}{c}\text { Tablets, syrup and } \\
\text { injection }\end{array}$ & Tablets \\
\hline
\end{tabular}

The results indicate that the proposed method is more sensitive than the literature methods . 


\section{CONCLUSIONS}

The developed spectrophotometric method for the assay of MCP is simple, sensitive, selective, inexpensive and exhibits a fair degree of precision and accuracy. Beer's law was obeyed over the concentration range of $5-300 \mu \mathrm{g} / 25 \mathrm{ml}$. with a molar absorptivity $3.1 \times 10^{4} 1 . \mathrm{mol}^{-1} . \mathrm{cm}^{-1}$ and a relative standard deviation of \pm 0.38 to $\pm 0.64 \%$ depending on concentration level. The method does not involve any critical reaction conditions and can be compared favorably with other existing methods. The proposed method can serve as an alternative method for the analysis of $\mathrm{MCP}$ in pure form and in pharmaceutical formulations.

\section{REFERENCES}

Abdel-Gawad, F.M. ; El-Gunidi, N.M. (1995). Spectrophotometric determination of metoclopramide and oxybuprocaine through ion pair formation with thiocyanate and molybdenum (V) or cobalt (II). Anal. Lett., 28, 1437-1447.

Ahmed, N.R. ; Ali, N.M. (2006). Spectrophotometric determination of metoclopramide in some pharmaceutical preparation via oxidative coupling reagent. J. Edu . Sci. , 18(4), 16-22.

Al-Arfaj, N.A. (2004). Flow-injection chemiluminescent determination of metoclopramide hydrochloride in pharmaceutical formulations and biological fluids using the $\left[\mathrm{Ru}(\text { dipy })_{3}\right]^{2+}$ permanganate system. Talanta , 62(2), 255-263.

Al-Ghabsha, T.S. ; Ahmed, R.A. ; Mahmood, H. Sh. (2004). Spectrophotometric study of some drugs using 2,3-dichloro-5,6-dicyano-p-benzoquinone (DDQ). J. Edu. Sci. , 16(4), $42-53$.

Al-Talib, S.M. ; Mohammed, S.A. (1996). Spectrophotometric assay of metoclopra-mide via oxidative coupling with phenothiazine and sodium metaperiodate. J. Edu. Sci. , 18(4), 16-22.

Amin, A.S. ; Ragab, G.H. (2003). Spectrophotometric methods for the determination of anti-emetic drugs in bulk and in pharmaceutical preparations. Anal. Sci., 19, 747751.

Attia, M.S ; Aboaly, M.M. (2010). Highly sensitive and selective spectrophotometric determination of metoclopramide hydrochloride in pharmaceutical tablets and serum samples using $\mathrm{Eu}^{3+}$ ion doped in sol-gel matrix. Talanta , 82(1), 78-84.

British pharmacopoeia, (1998). The Stationary Office under License from the controller of Her Majesty's stationary office, I, 888 p., II ,pp. 1810-1811.

Cossa, M.; Sanna, V.; Gavini, E.; Rassul, G. ; Giunchedi, P.(2008). Anew sensitive reversed phase chromatography method for the quantitative determination of metoclopramide in canine plasma. Anal. Lett. , 41(5), 767-778.

Farghaly, O.A. ; Taher, M.A. ; Naggar, A.H. ; El-Sayed A.Y.(2005). Square wave anodic stripping voltammetric determination of metoclopramide in tablet and urine at carbon paste electrode . J. Pharm. Biomed. Anal., 38(1), 14-20.

Hanna, G.M. ; Lau-Cam, C.A. (1991). $\mathrm{H}^{1}$ NMR spectroscopy assay method for metoclopramide in tablets and injections. Drug Der. Ind. Pharm., 17(7), 975-984. 
Khalil, N. A. (2010). Determination of metoclopramide hydrochloride by spectrophotometric and HPLC methods - Applications to pharmaceutical preparations. M.Sc. Thesis, University of Mosul, pp. 10, 23,24 .

Moussa, B.A. (2000). Determination of some aminobenzoic acid derivatives glafenine and metoclopramide. J. Pharm. Biomed. Anal. , 23(6), 1045-1055.

Omran, A.A.(2005). Individual and simultaneous spectrophotometric determination of dapsone and metoclopramide $\mathrm{HCl}$ in pharmaceutical dosage forms and synthetic binary mixtures, Chem. Pharm. Bull. (Tokyo) , 53(11), 1498-1501.

Patel, S.A. ; Patel, C.N. ; Patel, M.M. (2006). Visible spectrophotometric methods for the estimation of metoclopramide $\mathrm{HCl}$ in tablets. Indian J. Pharm. Sci., 68(3), 397-399.

Radwan, M.A.(1998). Determination of metoclopramide in serum by HPLC assay and its application to pharmacolcinetic study in rat. Anal. Lett., 31(14), 2397-2410.

Revanasiddappa, H.D. ; Manju, B. (2001). A spectrophotometric method for the determination of metoclopramide hydrochloride and dapsone. J. Pharm. Biomed. Anal. , 25(3-4), 631-637.

Revanasiddappa, H.D. ; Veena, M.A. (2006). Sensitive spectrophotometric determination of metoclopramide hydrochloride and dapsone in bulk sample and dosage forms. Sci. Asia , 32, pp.319-321.

Shaabani, N. ; Adergani, B.A. (2009). Novel molecularly imprinted polymers for the selective extraction and determination of metoclopramide in human serum and urine samples using high performance liquid chromatography. J. Chromatogr. B, 877(24), 2537-2544.

Shah, J. ; Rasul, J.M. ; Azam, K.M. ; Amin, S. (2005). Spectrophotometric determination of metoclopramide in pharmaceutical preparations. J. Anal.Chem. , 60(7), 633-635.

Tas, C. ; Ozkan, C.K. ; Savaser, A. ; Ozkan, Y. ; Tasdemir, U. ; Altunay, H. (2006). Nasal absorption of metoclopramide from different carbopol 981 based formulations: In vitro, ex vivo and in vivo evaluation. Eur. J. Pharm. Biopharm., 64(2), 246-254. 